\title{
Impact of Climate Variability on Water Resources: The Case of Marc Delorme-Cnra Station, Southeast of Ivory Coast
}

\author{
Charly Fernand Agoh ${ }^{1 *}$, Tacra Thierry Lekadou'2, Mahaman Bachir Saley ${ }^{1}$, \\ Bi Trazié Jérémie Gala ${ }^{1}$, Jean Homian Danumah', Pierre-Marie Janvier Coffi², \\ Zadjéhi Eric-Blanchard Koffi' ${ }^{4}$ Bi Tié Albert Goula ${ }^{3}$
}

\footnotetext{
${ }^{1}$ Laboratory of Water and Environmental Sciences and Techniques (LSTEE), UFR of Earth Sciences and Mineral Resources (STRM), Felix Houphouët Boigny University, Abidjan, Ivory Coast

${ }^{2}$ National Agronomic Research Center, Marc Delorme Research Station, Abidjan, Ivory Coast

${ }^{3}$ Laboratory, Geosciences and Environment, Training and Research Unit of Environmental Sciences and Management (UFR) of Environmental Sciences and Management, Nangui Abrogoua University (UNA), Abidjan, Ivory Coast

${ }^{4}$ Laboratory of Biology and Improvement of Plant Productions, UFR Sciences de la Nature, Peleforo Gon Coulibaly University, Korhogo, Ivory Coast

Email: ^charlenand@gmail.com, Thierry_tacra@yahoo.fr, basaley@yahoo.fr, gala_trazie@yahoo.fr, danumahjean@yahoo.fr, coffipierremariejanvier@gmail.com, koffiza-djehi@gmail.com, goulaba@gmail.com
}

\begin{abstract}
How to cite this paper: Agoh, C.F., Lekadou, T.T., Saley, M.B., Gala, B.T.J., Danumah, J.H., Coffi, P.-M.J., Koffi, Z.E.-B. and Goula, B.T.A. (2021) Impact of Climate Variability on Water Resources: The Case of Marc Delorme-Cnra Station, Southeast of Ivory Coast. Journal of Water Resource and Protection, 13, 726-749.
\end{abstract} https://doi.org/10.4236/jwarp.2021.139038

Received: July 3, 2021

Accepted: September 24, 2021

Published: September 27, 2021

Copyright ( 2021 by author(s) and Scientific Research Publishing Inc. This work is licensed under the Creative Commons Attribution International License (CC BY 4.0).

http://creativecommons.org/licenses/by/4.0/ (c) (i) Open Access

\begin{abstract}
This study aims to characterize the climatic variability in the South-East of Ivory Coast and to show its impact on the supply of water resources. To do this, statistical and hydrological methods were applied to climatic data collected at the Marc DELORME Research Station of the CNRA. The statistical trend tests on this data revealed a significant decrease in precipitation and an increase in temperature, insolation and evaporation. Statistical break methods indicate a rainfall break in 1982 which marks a modification of the rainfall regime thus translating a drop in rainfall of $15 \%$, a recession in the frequency of rainy days in general and in particular in rainfall heights between 10 and $30 \mathrm{~mm}$ and greater than $50 \mathrm{~mm}$. This break is accompanied by a shortening of the rainy seasons, with average rainfall durations ranging from 54 days (short rainy season) to 104 days (great rainy season). Despite the disturbances in the different seasons of the year, the monthly rainfall regimes in the area have not changed. The assessment of the effects of drought on water resources using the Standardized Precipitation and Evapotranspiration Index (SPEI) for three-time scales ( 1 month, 3 months and 12 months) indicates a severe drought ranging from $3 \%$ to $7 \%$ over the period 1961 to 2018 . However, despite the presence of this severe drought, the intensity of the drought was found to be moderate on all time scales. The Thorrnthwaite method was
\end{abstract}


used to highlight the impacts of this climatic variability on the region's water resources. The average annual recharge estimated at $402 \mathrm{~mm}$, has been reduced to $153 \mathrm{~mm}$ during a deficit period, a decrease of about $62 \%$. The average annual runoff, which was $294 \mathrm{~mm}$, fells to $257 \mathrm{~mm}$, a decrease of about $13 \%$. This recorded decrease in the water infiltrated after the rainfall break (1983-2018), explains the heterogeneous decrease in the depth of the water table.

\section{Keywords}

Climate Variability, Drought, Statistical Tests, Water Resource, Ivory Coast

\section{Introduction}

In recent decades, the global community has become increasingly interested in issues related to climate variability and change, as a result of the immediate impacts on the natural environment, on humans and on livelihoods [1]. Among these is drought, which has complex impacts on many sectors of the economy such as water resources, agriculture and natural ecosystems [2]. Drought has affected both tropical bands of our planet, especially the majority of the Sahelian countries of West Africa since the 1970s and 1980s [3]. This climate variability poses a major threat to growth and sustainable development, as well as an impediment to the Millennium Development Goals (MDGs). Indeed, according to [4], poor communities will be the most vulnerable due to their limited adaptive capacities and high dependence on climate-sensitive resources such as water resources and agricultural production systems. In West and Central non-Sahelian Africa, many studies mention the disadvantages of drought in the late 1960s and early 1970s [5]. The most significant effects have been the long-term reduction in rainfall, the decrease in the contribution of the wettest months to cumulative rainfall, the shifting of the rainy seasons, the increase in the number of dry spells, the decrease in piezometric levels and the drop in river flows [6] [7] with disadvantages for agriculture and natural resource availability [8]. Ivory Coast is not immune to these phenomena. Ivorian agriculture is a key sector of the economy. It employs $60 \%$ of the population, contributes to $34 \%$ of GDP and represents $2 / 3$ of export resources [9]. In this context of climatic variability, this agriculture remains limited in terms of its production because it is essentially rain-fed and therefore subject to climatic hazards [10] [11]. The south-east of the country, which includes the study area, is the main place for coconut production with several industrial plantations and numerous small private farms on which more than 20,000 families depend [12]. However, coconut production in this area has dropped in these recent decades due to the pronounced effects of water stress [13]. In order to better understand the influence of climate on the Ivorian coconut grove, a preliminary study using climatic and water table depth data is warranted to appreciate the effects due to its variability. The present study aims 
to characterize the climatic variability in the South-East of Ivory Coast between 1961 and 2018.

\section{Material and Methods}

\subsection{Study Area}

The study was carried out on the Marc Delorme Research Station (Figure 1), of the National Agricultural Research Center (CNRA). This Station is located in the south-east of Ivory Coast, between $5^{\circ} 14^{\prime}$ and $5^{\circ} 15^{\prime}$ North latitude and $3^{\circ} 54^{\prime}$ and $3^{\circ} 55^{\prime}$ West longitude. It was classified as an international heritage site by the FAO in 1999, as it houses the international collection of coconut trees for Africa and the Indian Ocean, with nearly 99 accessions [14]. The site covers an area of 788 ha, also known as "500 genetic block", at $12 \mathrm{~km}$ from the Abidjan-Bassam road, north-east of Gonzagueville. The Station is based on soil with sesquioxide [15], ferralitic types leached into bases, containing high levels of fine sands with some clay at depth and low levels of organic matter [16]. The soil presents textures and structures favourable to water infiltration. The climate of the area belongs to the equatorial transitional regime. It is an Attiéan type of climate where the rhythm of the seasons is regulated by the movement of the Intertropical Front (ITF). It is characterized by 4 seasons, 2 rainy seasons (April to July and October to November) and 2 dry seasons (December to March and August to September) [17] [18]. The average annual rainfall is between 1165.6 and 2755.7 $\mathrm{mm}$. The geological environment of the area belongs to the sedimentary basin of Côte d'Ivoire, and is mostly composed of Tertiary clayey sands and Quaternary sands of the coast with a simple geology [19]. On the hydrogeological plan, the aquifers presents are continuous and characteristic of the sedimentary basin. These are the Quaternary aquifer and the Mio-Pliocene (Continental Terminal) and Upper Cretaceous (Maestrichtian) aquifers [20].

\subsection{Study Data}

The climatic data used in this study are rainfall, air temperature, relative air humidity, evaporation and insolation. They have been collected from the meteorological service of the Marc Delorme research station of the National Agricultural Research Centre (CNRA). Rainfall and air temperature cover the period from 1961 to 2018. But relative humidity, evaporation and insolation have been taken from 1977 to 2018 and piezometrics data's was obtained over the period from 1992 to 2018 , due to the availability of data. piezometrics data's were taken on a monthly time step in order to have a better approach of the its variations. These data are fairly homogeneous, of good quality and representative of the study area.

\subsection{Methods of Study}

\subsubsection{Methods for the Identification of Climate Variability}

The climatic variability was highlighted by a statistical analysis of the climatic 
factors. Thus, the mean of the variables considered, their standard deviation and their coefficient of variation were calculated.

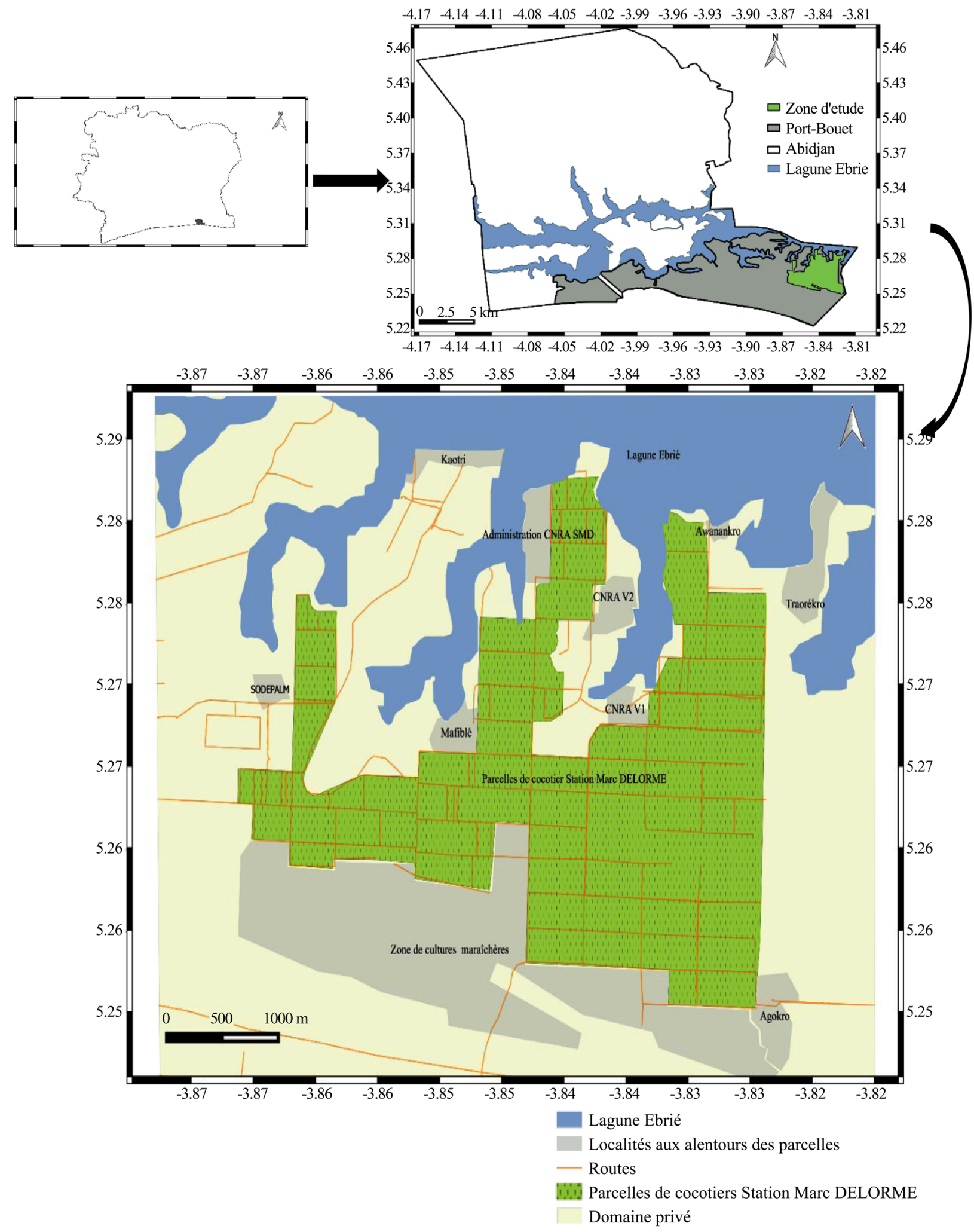

Figure 1. Geographical location of the Marc Delorme station. 
1) Trend and break detection test

In order to detect possible changes in the evolution of the climatic parameters, trend tests (Mann-Kendall test and Linear Regression test) and breakpoint tests (Pettitt test, Hubert segmentation procedure, Lee and Heghinian Bayesian procedure) were used. These different breakage methods were carried out using the Khronostat software developed by the Institut de Recherche pour le Développement (IRD) and the University of Montpellier [21].

\section{2) Characterization and identification of drought}

\section{Standardized Precipitation and Evapotranspiration Index (SPEI)}

The SPEI has been used for its multi-scalar character allowing it to detect, monitor and analyse different types of drought at different temporal scales [2]. Furthermore, [22] have indicated that drought indices should be statistically robust, easy to calculate and have a clear and understandable calculation procedure. All these requirements are fulfilled by the PESI [23]. With temperature data, the SPEI is particularly well adapted to analyse the effect of global warming on drought conditions [24]. Thus, the SPEI for the study area were calculated from monthly precipitation and temperature data over the period 1961 to 2018 at 1-month, 3-month and 12-month time scales. These calculations were performed in RStudio 4.0.3 using the SPEI package according to the method mentioned in the study of [23].

\subsubsection{Methods for Modeling the Length of the Rainy Season}

\section{1) Determination of rainy seasons}

In this study, the start and end dates of the rainy season were calculated from the agro-climatic definitions proposed by [25] and based on empirical rainfall thresholds. This method was adapted to the specificities of Ivory Coast by [26] and [27]. The criteria used are a slight modification of those in [27] by [28]. In our area, the rainy season starts on February 1st, when at least $20 \mathrm{~mm}$ of rainfall is recorded on two consecutive days without dry spells lasting more than 7 days within 30 days of the date indicated. The short rainy season starts when, from August 15th onwards, more than $10 \mathrm{~mm}$ of rainfall is recorded on two consecutive days without dry spells lasting more than 7 days within the following 30 days. The main rainy season ends on July 1st, when a soil capable of holding 70 $\mathrm{mm}$ of available rainwater has completely exhausted this stock following a daily loss of $4 \mathrm{~mm}$ through evapotranspiration. Also, no significant rainfall should be recorded within 20 days of the date obtained. For the end of the short rainy season, calculations are made from November 1st, using the same criteria as above. The length of the season is expressed as the difference between the end date and the start date of the rainy season.

\section{2) Forecasting the duration of rainy seasons}

The method used to predict the duration of the rainy season is simple linear regression, which relates the duration of the rainy season to the start date of the season according to the following equation (Equation (1)):

$$
Y=a x+b
$$


with:

$Y$ : duration of the rainy season; $x$. start date of the rainy season.

The evaluation of the models was done through statistical criteria (correlation coefficient R) and a graphical criterion. Two variables were considered correlated if their correlation coefficient was greater than or equal to 0.8 . The significance of this threshold was analysed.

\subsubsection{Method for Characterizing the Impact of Climate on Groundwater} The groundwater recharge estimation method used in this study is based on the calculation of the water balance using the Thornthwaite method [18]. The choice of this method is explained by the availability of climatic data such as rainfall and temperature. The main parameters sought are Potential Evapotranspiration (PET), actual evapotranspiration (ETa) and balance sheet (P-ETa). Subsequently, two components ensuring the recharge of the water table were determined. The first, the runoff or runoff $(\mathrm{R})$ and the second component is represented by infiltration (I). The spatio-temporal evolution of the depths of the water table in different climatic seasons was carried out. The water table depth data were exported to the Surfer 11.0 software where a kriging interpolation was performed to generate the thematic maps.

\section{Results}

\subsection{Impact of Climate Variability in the Area}

\subsubsection{Dispersion Characteristics in the Series of Climatic Factors}

The data for the climatic factors in the study area show little dispersion overall, with low coefficients of variation (Cv) ranging from $1 \%$ to $20 \%$ (Table 1 ). Consequently, these climatic data are on the whole reliable for characterising the evolution of the climate in the area.

\subsubsection{Detection of Trends in the Series of Climatic Factors}

The results of the indices of gradual changes in the climate factor series are presented in Table 2. Negative trend index indicate a decreasing trend and positive trend index indicate an increasing trend in the climate variables. As concerning trend indexes, the average temperature series (minimum temperature, maximum temperature), of insolation and evaporation show a significant upward trend in the Mann-Kendall and linear regression tests. In the precipitation series, a significant downward trend was detected with the Mann-Kendall and linear regression tests. In contrast, in the relative humidity series, the Mann-Kendall and linear regression tests did not detect any gradual change.

\subsubsection{Detection of Breaks in the Rainfall Series}

The annual rainfall series show breaks mostly between 1976 and 1982 (Table 3). The detection of breaks by the Pettitt test (1982) was significant at the $90 \%$ and $95 \%$ confidence level with an exceedance probability of 0.027 . This break is confirmed by the Hubert segmentation procedure. The break date with the Bayesian 
method of Lee and Heghinian is located in 1976 with an exceedance probability of 0.1746 . These detected breaks result in a decrease of the mean annual rainfall during the period 1976-1982 and allowed to determine the different periods of rainfall fluctuation.

Table 1. Statistical characteristics of climatic factors in the study area.

\begin{tabular}{cccccc}
\hline Variables & Minimum & Maximum & Average & $\begin{array}{c}\text { Standard } \\
\text { deviation }\end{array}$ & $\begin{array}{c}\text { Coefficient } \\
\text { of variation }\end{array}$ \\
\hline Rainfall & 1165.6 & 2755.7 & 1828.3 & 366.1 & $20 \%$ \\
Average temperature & 25.5 & 27.1 & 26.2 & 0.3 & $1 \%$ \\
Minimum temperature & 21.6 & 23.7 & 22.8 & 0.4 & $1 \%$ \\
Maximum temperature & 28.8 & 35.7 & 30.1 & 1 & $3 \%$ \\
Sunhine & 1730.2 & 2456.3 & 2163 & 187.3 & $8 \%$ \\
Air humidity & 78.7 & 88.8 & 87 & 1.8 & $2 \%$ \\
\hline
\end{tabular}

Table 2. Trend indices for the climate factor series.

\begin{tabular}{|c|c|c|}
\hline Variables & Tests & Trends indices (\%) \\
\hline \multirow[b]{2}{*}{ Rainfull } & MK & $-95.86 \%$ \\
\hline & $\mathrm{RL}$ & $-93.55 \%$ \\
\hline \multirow{2}{*}{ Average Temperatu } & MK & $98.57 \%$ \\
\hline & $\mathrm{RL}$ & $97.60 \%$ \\
\hline \multirow{2}{*}{ Min. Temperatur } & MK & $98.42 \%$ \\
\hline & RL & $96.57 \%$ \\
\hline \multirow{2}{*}{ Max. Temperatur } & MK & $99.87 \%$ \\
\hline & RL & $99.81 \%$ \\
\hline \multirow[b]{2}{*}{ Relative Humid } & MK & $-4.64 \%$ \\
\hline & RL & $32.96 \%$ \\
\hline \multirow{2}{*}{ Sunshine } & MK & $99.97 \%$ \\
\hline & RL & $99.98 \%$ \\
\hline \multirow{2}{*}{ Evaporation } & MK & $92.55 \%$ \\
\hline & $\mathrm{RL}$ & $90.37 \%$ \\
\hline
\end{tabular}

Bolded numbers indicate significant trends at the 10\% risk; MK: Mann-Kendall test; LR: linear regression test.

Table 3. Results of break tests on annual precipitation.

\begin{tabular}{cccccc}
\hline $\begin{array}{c}\text { Observation } \\
\text { period }\end{array}$ & Pettit test & Probability & $\begin{array}{c}\text { Lee and } \\
\text { Heghinian }\end{array}$ & Probability & $\begin{array}{c}\text { Hubert's } \\
\text { segmentation }\end{array}$ \\
\hline $1961-2018$ & 1982 & 0.027 & 1976 & 0.1746 & $1976 ; 1982$ \\
\hline
\end{tabular}




\subsubsection{Seasonal Variability of Rainfall before and after Break}

The rainfall averages before the breaks remain higher than those after the breaks. They are respectively $2010 \mathrm{~mm}$ and $1709.9 \mathrm{~mm}$, corresponding to a decrease of $300.1 \mathrm{~mm}$ (15\%) (Table 4). This decrease affects the different dry and rainy seasons as well as the short dry seasons with water deficits from 5\% to $25 \%$ (Table 5). On the other hand, a slight recovery is observed in the short rainy seasons. In general, the drop in rainfall affects the different seasons.

\subsubsection{Interannual Variability of Rainy Day Frequencies and Rainfall Classes}

The proportions occupied by the different rainfall classes are recorded in Table 6. Class P1 (1 to $10 \mathrm{~mm}$ ) represents $54.04 \%$, class P2 (10 to $30 \mathrm{~mm}$ ) represents $28.15 \%$, the classes $\mathrm{P} 3$ (30 to $50 \mathrm{~mm}$ ) and $\mathrm{P} 4(>50 \mathrm{~mm}$ ) represent respectively $9.37 \%$ and $7.43 \%$ for a total number of 5732 rainy days. These results show that rainfall of 1 to $30 \mathrm{~mm}$ (P1 and P2) constitutes the bulk of the rainfall in the area. Rainfall $>50 \mathrm{~mm}$ has the lowest occurrence. The results of Pettit's test and $\mathrm{Hu}-$ bert's segmentation procedure applied to the rainfall classes (P1, P2, P3 and P4) over the period from 1961 to 2018 are shown in Table 7. The rainy day series of classes P2 and P4 are affected by breaks in stationarity which are observed in 1981 and 1982. For the series of classes P1 and P3, no break was observed. The fluctuation rate of the different rainy day classes is shown in Table 8. The break year 1982 was used as the reference year. The analysis of this table shows that the rainfall recession in the area is due to a decrease in rainy days between $1 \mathrm{~mm}$ and $30 \mathrm{~mm}$ (P1 and P2) and more than $50 \mathrm{~mm}$ (P4). P1, which is the most frequent class $(54.04 \%)$, is the least affected by the decrease in rainy days $(8.47 \%)$. The number of rainy days from $10 \mathrm{~mm}$ to $30 \mathrm{~mm}$ (P2) decreased by $32.50 \%$ and the number of rainy days $>50 \mathrm{~mm}$ (P4) by $40 \%$. There was no significant change in the P3 class $(30-50 \mathrm{~mm})$. In the area as a whole, the number of rainy days decreased by $17.35 \%$.

Table 4. Precipitation deficit before and after the breakdown of the Pettitt Test.

\begin{tabular}{ccccc}
\hline Observation period & Reference & Average before break & Average after break & Deficit (\%) \\
\hline $1961-2018$ & 1982 & 2010 & 1709.9 & 15 \\
\hline
\end{tabular}

Table 5. Seasonal rainfall evolution before and after break.

\begin{tabular}{cccccc}
\hline \multirow{2}{*}{ Seasons } & Before break & After break & $\begin{array}{c}\text { Decrease } \\
(\mathrm{mm})\end{array}$ & $\begin{array}{c}\text { Increase } \\
(\mathrm{mm})\end{array}$ & Deficit (\%) Excess (mm) \\
\cline { 2 - 5 } Average & Average & 221 & 41 & 15 \\
GSP & 1365 & 1027 & 338 & 25 \\
PSS & 108 & 103 & 5 & 5 & 12 \\
PSP & 298 & 340 & & 42 & \\
\hline
\end{tabular}

GSS: great dry season; GSP: great rainy season; PSS: short dry season; PSP: short rainy season. 
Table 6. Percentages of rainy-day classes over the period 1961-2018.

\begin{tabular}{|c|c|c|c|c|c|c|c|}
\hline \multicolumn{2}{|c|}{ P1 (1 to $10 \mathrm{~mm})$} & \multicolumn{2}{|c|}{$\mathrm{P} 2$ (10 to $30 \mathrm{~mm}$ ) } & \multicolumn{2}{|c|}{ P3 (30 to $50 \mathrm{~mm}$ ) } & \multicolumn{2}{|c|}{$\mathrm{P} 4(>50 \mathrm{~mm})$} \\
\hline $\begin{array}{l}\text { Number of } \\
\text { rainy days }\end{array}$ & Percentage & $\begin{array}{l}\text { Number of } \\
\text { rainy days }\end{array}$ & Percentage & $\begin{array}{l}\text { Number of } \\
\text { rainy days }\end{array}$ & Percentage & $\begin{array}{l}\text { Number of } \\
\text { rainy days }\end{array}$ & Percentage \\
\hline 3155 & $54.04 \%$ & 1614 & $28.15 \%$ & 537 & $9.37 \%$ & 426 & $7.43 \%$ \\
\hline \multicolumn{8}{|c|}{ Total number of rainy days $=5732$} \\
\hline
\end{tabular}

Table 7. Breaks tests results for the period 1961-2018.

\begin{tabular}{ccc}
\hline & \multicolumn{2}{c}{ Breakdown dates } \\
\hline Rain classes & Pettitt test & Hubert's segmentation \\
\hline P1 $(1$ to $10 \mathrm{~mm})$ & Absence of break & Absence of rupture \\
P2 $(10$ to $30 \mathrm{~mm})$ & 1982 & 1982 \\
P3 $(30$ to $50 \mathrm{~mm})$ & Absence of break & Absence of rupture \\
P4 $(>50 \mathrm{~mm})$ & Absence of break & 1981 \\
\hline
\end{tabular}

Table 8. Fluctuation of rainy days classes after the 1982 break.

\begin{tabular}{cccccc}
\hline & $\mathbf{P}$ & $\begin{array}{c}\text { P1 } \\
(\mathbf{1} \text { to } \mathbf{1 0} \mathbf{~ m m})\end{array}$ & $\begin{array}{c}\text { P2 } \\
(\mathbf{1 0} \text { to } \mathbf{3 0} \mathbf{~ m m})(\mathbf{3 0} \text { to } \mathbf{5 0} \mathbf{~ m m})\end{array}$ & $\begin{array}{c}\text { P4 } \\
(>\mathbf{5 0} \mathbf{~ m m})\end{array}$ \\
\hline 1982 (reference) & 121 & 59 & 40 & 9 & 15 \\
Average rainy days (1983-2018) & 100 & 54 & 27 & 9 & 9 \\
Deficit & 21 & 5 & 13 & 0 & 6 \\
Percentage (\%) & 17.35 & 8.47 & 32.5 & 0 & 40 \\
\hline
\end{tabular}

\subsection{Climate Variability and Rainy Season}

\subsubsection{Variations in the Start and end Dates of Rainy Seasons}

Table 9 shows the variations in the start and end dates of the rainy season at the Marc Delorme research Station. The start dates of the main rainy season of this bimodal regime are on average in April (13 April) with a standard deviation of 20 days. July is the late date for the start of the main rainy season, while the early date is in March. The periods from the first decade of August (8 September) to the second decade of December (27 December) constitute the late end dates. The early end dates are in the second decade of July. The start of the short rainy season occurs in October ( 14 October) with a standard deviation of 23 days. October (29 October) and November (24 November) represent the late start dates of the rainy season, while the early dates are occurs in September. As for the end dates, the early ones are between the third decade of November (30 November) and the first decade of December (2 December). The late end dates are in the third decade of December.

\subsubsection{Analysis and Forecasting of Rainy Season Duration}

Table 10 presents the results on the duration of the rainy seasons. The average duration of the long rainy season is 112 days with a standard deviation of 22 days. The short rainy season lasts on average 57 days with a standard deviation of 14 days. 
Table 9. Start and end dates of the great and short rainy seasons.

\begin{tabular}{|c|c|c|c|c|c|c|c|}
\hline Seasons & Minimum & $20 \%$ & Average & $50 \%$ & $80 \%$ & Maximum & $\begin{array}{l}\text { Standard } \\
\text { deviation }\end{array}$ \\
\hline \multicolumn{8}{|c|}{ Starting date of the rainy season } \\
\hline $\begin{array}{l}\text { Start of the great } \\
\text { rainy season }\end{array}$ & 16-Mar. & 28-Mar. & 13-Apr. & 11-Apr. & 25-Apr. & 13-Jul. & 20 \\
\hline $\begin{array}{l}\text { Start of the short } \\
\text { rainy season }\end{array}$ & 15-Sep. & 24-Sep. & 14-Oct. & 11-Oct. & 29-Oct. & 24-Nov. & 23 \\
\hline \multicolumn{8}{|c|}{ Date of the end of the short rainy season } \\
\hline $\begin{array}{l}\text { End of the great } \\
\text { rainy season }\end{array}$ & 17-Jul. & 23-Jul. & 3-Aug. & 29-Jul. & 8-Sept. & 27-Dec. & 24 \\
\hline $\begin{array}{l}\text { End of the short } \\
\text { rainy season }\end{array}$ & 30-Nov. & 2-Dec. & 13-Dec. & 13-Dec. & 26-Dec. & 30-Dec. & 11 \\
\hline
\end{tabular}

Table 10. Duration of rainy seasons (days).

\begin{tabular}{cccccccc}
\hline Seasons & Minimum & $\mathbf{2 0 \%}$ & Average & $\mathbf{5 0 \%}$ & $\mathbf{8 0 \%}$ & Maximum & $\begin{array}{c}\text { Standard } \\
\text { deviation }\end{array}$ \\
\hline $\begin{array}{c}\text { Duration of the great } \\
\text { rainy season }\end{array}$ & 123 & 117 & 112 & 109 & 136 & 167 & 22 \\
$\begin{array}{c}\text { Duration of the short } \\
\text { rainy season }\end{array}$ & 76 & 69 & 57 & 64 & 57 & 36 & 14 \\
\hline
\end{tabular}

After calibration using simple linear regressions, two prediction equations for the duration of the rainy season $(\mathrm{Y})$ as a function of the start date of the rains (X) according to the seasons were obtained (Table 11). Very high correlation coefficients (in absolute values) were obtained between the starting date of the rains and the duration of the rainy season. They are 0.88 in the long rainy season and 0.97 in the short rainy season.

\subsubsection{Analysis of Rainy Season Start Dates before and after the Break}

The onset dates of the major rainy season, prior to the 1982 break, averaged March (25 March) with a standard deviation of 35 days (Table 12). June was the late date for the start of the main rainy season, while the early date was in March. The periods from the first dekad of August (15 August) and December (27 December) were the late end dates. The early end dates were in the first and second dekad of July. The average start date of the short rainy season was in October (8 October) with a standard deviation of 18 days. October (19 October) and November (11 November) were the late start dates of the short rainy season, while the early rainy season dates were in September. The early and late ends were observed in November and December respectively. After the break in 1982, there was a shortening of the duration of the rainy seasons with average rainfall durations ranging from 54 days (short rainy season) to 104 days for the great rainy season (Table 13). Thus, over the period 1961 to 2018, a shortening of the rainy season durations can be observed after the 1982 break (1983 to 2018). During the period 1983 to 2018, the onset dates of the main rainy season are on average in April (22 April) with a standard deviation of 37 days. May (3 May) 
and July (13 July) represent the late onset dates of the major rainy season, while the early dates are in March. The end of the long rainy season occurs in August (4 August) with an early end of the rains in July and a late end of the rains occurring between 7 August and 28 October. On average, the short rainy season starts in October (21 October). The early and late rainy season dates correspond to September and November. The end date of the early rains is recorded in November. December marks the end of the short rainy season. The major rainy season from 1961 to 1982 lasted on average 137 days with a standard deviation of 20 days. The short rainy season averaged 65 days with a standard deviation of 8 days (Table 13).

Table 11. Simple linear regression of the duration of the rainy season as a function of the start date of the rains.

\begin{tabular}{cccc}
\hline Seasons & Forecasting equation & Coefficient of determination $\left(R^{2}\right)$ & Correlation coefficient $(R)$ \\
\hline Great rainy season & $\mathrm{Y}=0.4522 \mathrm{X}+76.01$ & 0.78 & 0.88 \\
Short rainy season & $\mathrm{Y}=-0.5403 \mathrm{X}+215.7$ & 0.95 & 0.97 \\
\hline
\end{tabular}

$\mathrm{X}$ : Start of the rainy season; Y: Duration of the rainy season.

Table 12. Starting dates of the rainy seasons before and after break (1982) by the Pettitt test.

\begin{tabular}{|c|c|c|c|c|c|c|c|}
\hline Seasons & Minimum & $20 \%$ & Average & $50 \%$ & $80 \%$ & Maximum & Standard deviation \\
\hline \multicolumn{8}{|c|}{ Before 1982 break } \\
\hline Start of the great rainy season & Mar.-2 & Mar.-3 & Mar.-25 & Mar.-22 & Apr.-17 & Jun.-4 & 35 \\
\hline Start of the short rainy season & Sep.-21 & Sep.-24 & Oct.-8 & Oct.-7 & Oct.-19 & Nov.-11 & 18 \\
\hline End of the great rainy season & Jul.-7 & Jul.-17 & Aug.-9 & Aug.-3 & Aug.-15 & Dec.-27 & 33 \\
\hline End of the short rainy season & Nov.-23 & Nov.-27 & Dec.-12 & Dec.-15 & Dec.-21 & Dec. -27 & 11 \\
\hline \multicolumn{8}{|c|}{ After 1982 break } \\
\hline Start of the great rainy season & Mar.-29 & Apr.-15 & Apr.-22 & Apr.-17 & May-3 & Jul.-13 & 37 \\
\hline Start of the short rainy season & Sep.-19 & Sep.-25 & Oct.-21 & Oct.-19 & Oct. -9 & Nov. -24 & 23 \\
\hline End of the great rainy season & Jul.-4 & Jul.-23 & Aug. -4 & Aug.-1 & Aug. -7 & Oct.-28 & 39 \\
\hline End of the short rainy season & Nov.-14 & Dec.-1 & Dec.-14 & Dec.-15 & Dec.-24 & Dec.-28 & 17 \\
\hline
\end{tabular}

Table 13. Duration of rainy seasons (days) before and after the break (1982) by the Pettitt test.

\begin{tabular}{|c|c|c|c|c|c|c|c|}
\hline Seasons & Minimum & $20 \%$ & Average & $50 \%$ & $80 \%$ & Maximum & Standard deviation \\
\hline \multicolumn{8}{|c|}{ Before 1982 break } \\
\hline Duration of the great rainy season & 127 & 136 & 137 & 134 & 120 & 176 & 20 \\
\hline Duration of the short rainy season & 62 & 63 & 65 & 69 & 63 & 46 & 8 \\
\hline Duration of the great rainy season & 97 & 99 & 104 & 105 & 95 & 107 & 5 \\
\hline Duration of the short rainy season & 55 & 66 & 54 & 58 & 76 & 34 & 14 \\
\hline
\end{tabular}




\subsection{Drought Characterization and Identification}

\section{Standardized Precipitation and Evapotranspiration Index (SPEI)}

The results of these three drought indices indicate in particular that the SPEI time series at these time scales show seasonal and interannual variability of drought in the region (Figure 2). Positive and negative indices exist at all scales (1 month, 3 months and 12 months). However, the 12-month scale has the lowest negative indices in the series representing severely dry years ranging from -1.55 to -1.98 . The driest years are 1989, 1998, 2013 and 2016 with SPEI values of $-1.78,-1.98,-1.55$ and -1.75 respectively. The 1 -month, 3 -month and 12-month time scales show a common surplus period from 1961 to 1982 and a deficit period from 1983 to 2018 . The study area is marked by a rarity of extreme wet years in the data series considered. There are 1 (1982) for the SPEI-1, 2 (1976; 1982) for the SPEI-3 and 1 (1963) for the SPEI-12. These wet years represent $1.72 \%$ to $3.44 \%$ of the observations years. Similarly, for all time scales,
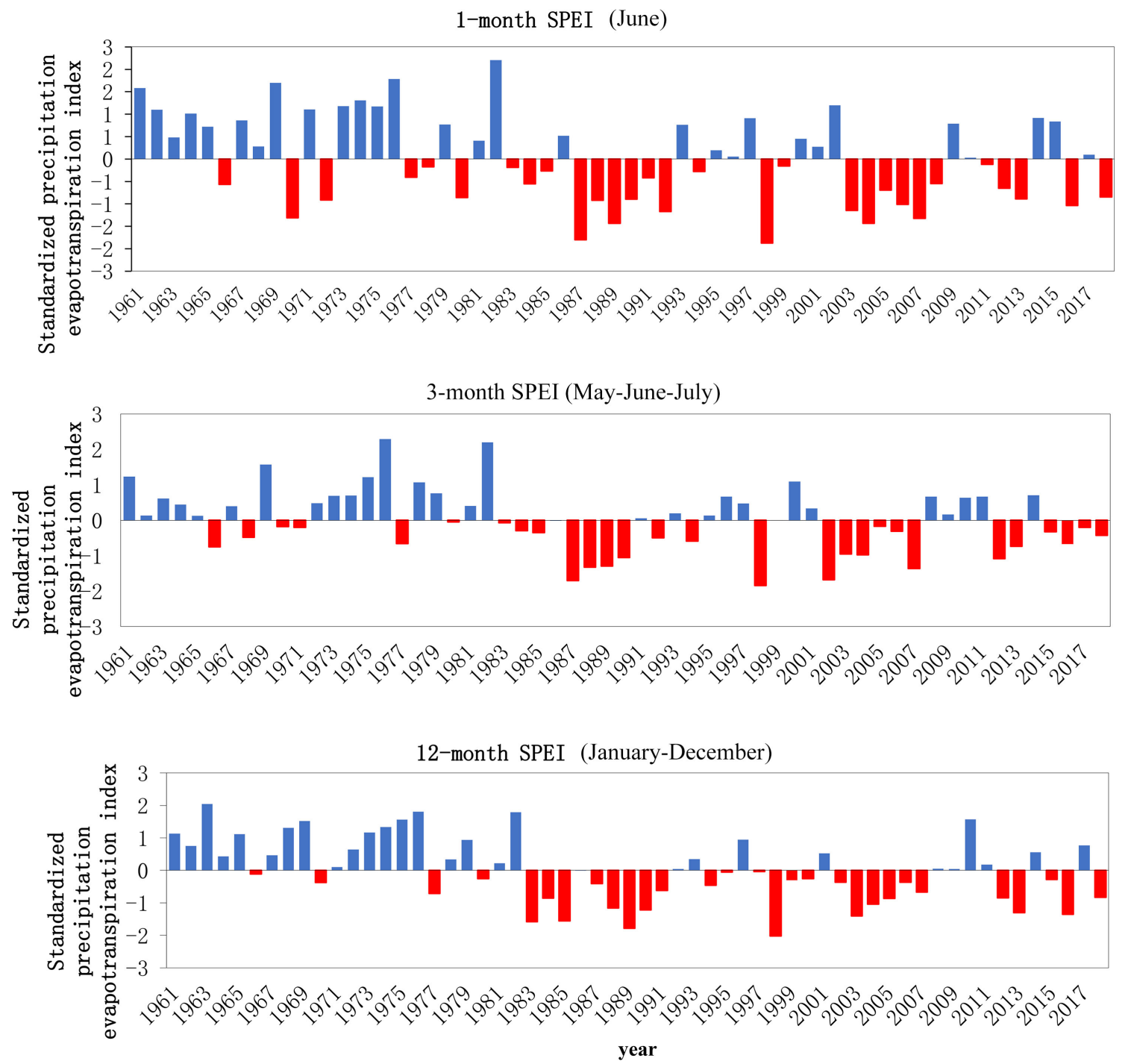

Figure 2. Temporal evolution of SPEI values on 1.6 and 12 month time scales for the study area from 1961 to 2018. 
$1.72 \%$ to $8.62 \%$ of years are classified as extremely wet, $13.79 \%$ to $18.96 \%$ as moderately wet, $8.62 \%$ to $13.79 \%$ as moderately dry and $3.44 \%$ to $6.89 \%$ as severely dry (Table 14). The absence of extreme drought years in the study area is noted. Overall, over the study period from 1961 to 2018, the SPEI values at different time scales are more marked for droughts of moderate to severe intensity.

\subsection{Impact of Climate on Groundwater}

\subsubsection{Piezometric Evolution}

\section{1) Interannual piezometric evolution}

The coupled monitoring of rainfall and piezometric variations in relation to piezometers P152A, P152B, P124, P050, P071, P023, P040, M52, M92 and M80 over the period 1992 to 2018 has made it possible to determine the temporal relationship between these two parameters (Figure 3). These piezometric records show the interannual trends of increasing or decreasing water table depths at the ten piezometers. Figure 3 show the influence of the rainfall factor on the depth of the water table and its impact on fluctuations on the water table. The effect of the wet and dry years can be clearly observed on these different figures. A general increase on the piezometric level in years with high rainfall and an interannual downward trend in years with low rainfall is observed. The analysis of the graphs below shows a regression of the water table during dry periods and also the important role of rainfall in wet years in the recharge of the water table.

\section{2) Piezometry of the water table in low water}

The piezometric map of the water table in low water (Figure 4) was drawn up using piezometric data from February over the period 1992-2018. The piezometric level was between 2 and $5.4 \mathrm{~m}$. The piezometers in south, close to the Ebrié lagoon, maintain a high water table (less than $3 \mathrm{~m}$ ) in the dry season.

\section{3) Piezometry of the water table in high water}

The piezometric level in the study area was studied for high water during the period 1992-2018. July was the month in which the water table reached its maximum level. The piezometrics data's for that month were therefore used to produce the piezometric map during high water periods (Figure 5). The piezometric level varied between 1.4 and $2.4 \mathrm{~m}$. In general, a high water table level in all piezometers was observed in July, at the end of the main rainy season.

Table 14. Variation of wet and dry periods in the study area.

\begin{tabular}{|c|c|c|c|c|c|c|}
\hline \multirow[b]{2}{*}{ Classes } & \multicolumn{3}{|c|}{ Years } & \multicolumn{3}{|c|}{ Percentage (\%) } \\
\hline & SPEI-1 & SPEI-3 & SPEI-12 & SPEI-1 & SPEI-3 & SPEI-12 \\
\hline Extremely wet (SPEI > 2) & 1 & 2 & 1 & 2 & 3 & 2 \\
\hline Very wet $(1.50<$ SPEI < 1.99) & 4 & 1 & 5 & 7 & 2 & 9 \\
\hline Moderately wet $(1.00<$ SPEI < 1.49) & 11 & 8 & 9 & 19 & 14 & 15 \\
\hline Normal $(-0.99<$ SPEI < 0.99) & 17 & 19.5 & 15.5 & 59 & 67 & 53 \\
\hline Moderately dry $(-1<$ SPEI $<-1.49)$ & 6 & 5 & 8 & 10 & 9 & 14 \\
\hline Very dry $(-1.50<$ SPEI $<-1.99)$ & 2 & 3 & 4 & 3 & 5 & 7 \\
\hline Extremely dry $(\mathrm{SPEI}<-2)$ & 0 & 0 & 0 & 0 & 0 & 0 \\
\hline
\end{tabular}




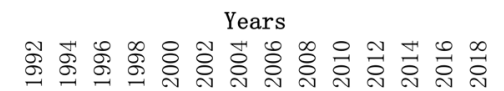
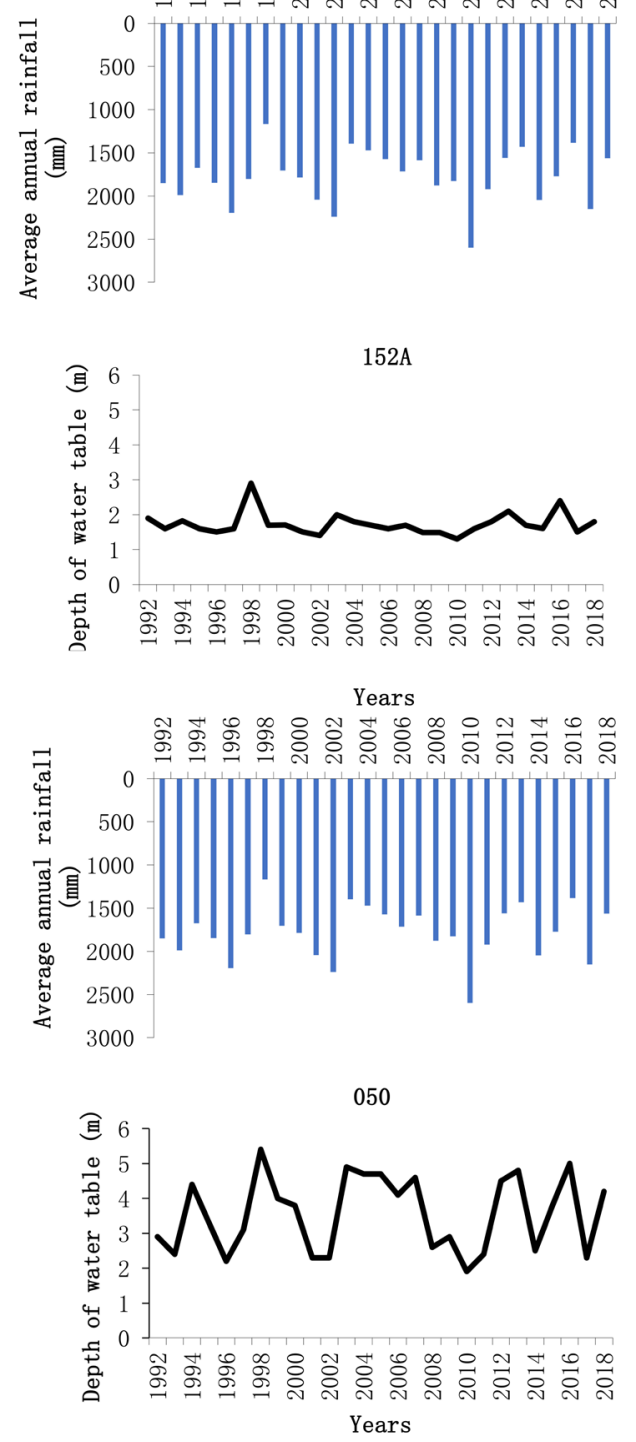

Years

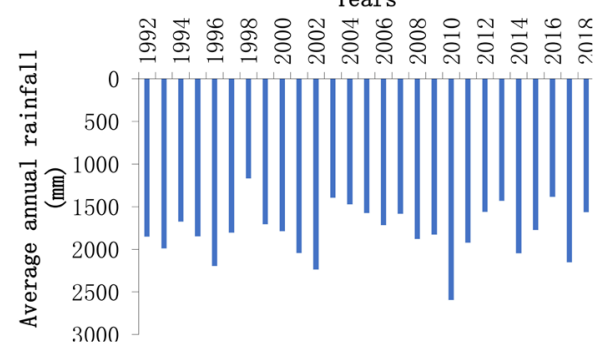

071

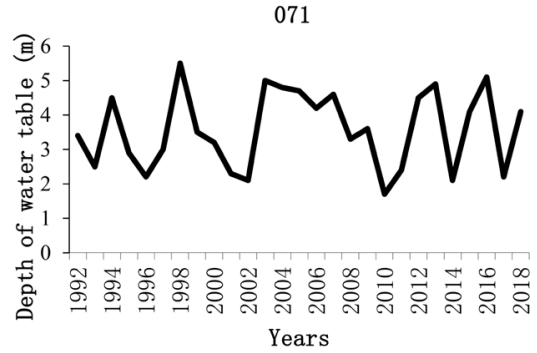

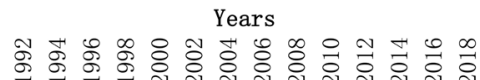

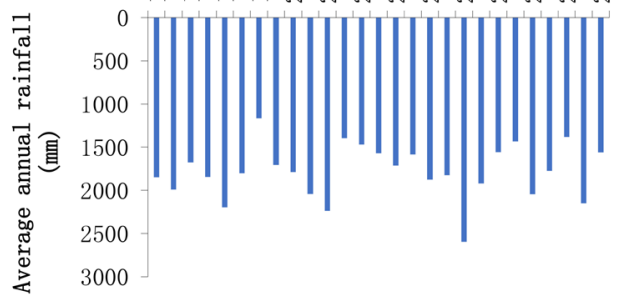

152B
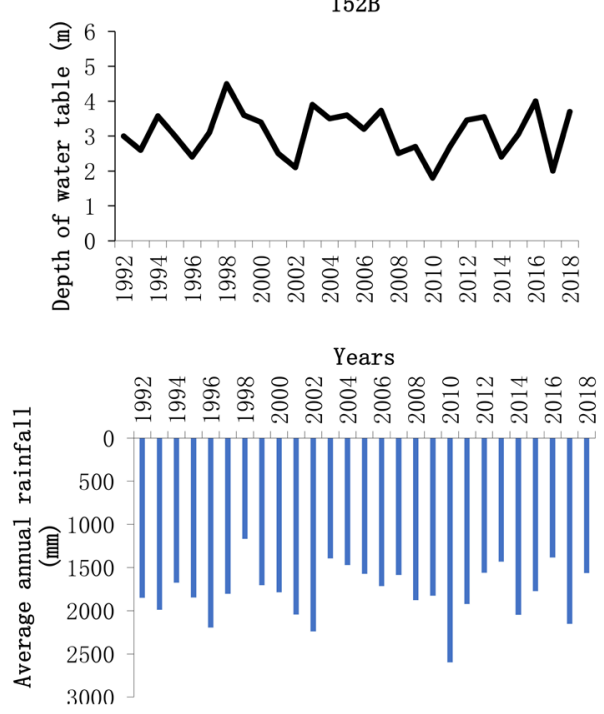

023

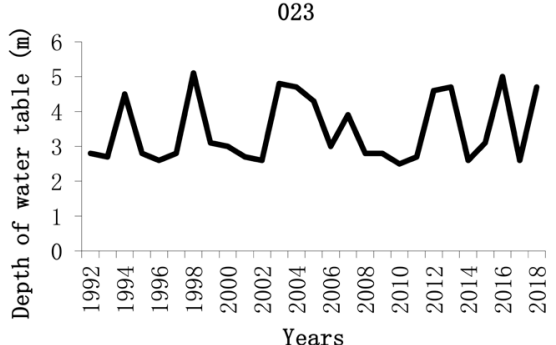

Years

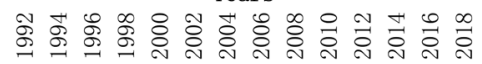

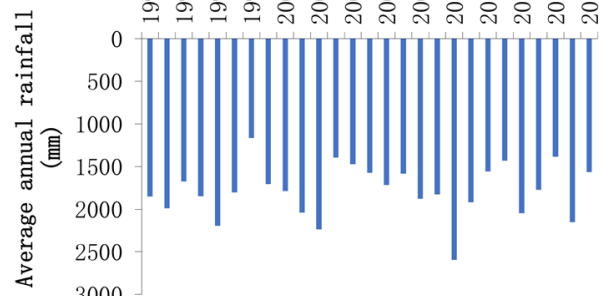

3000

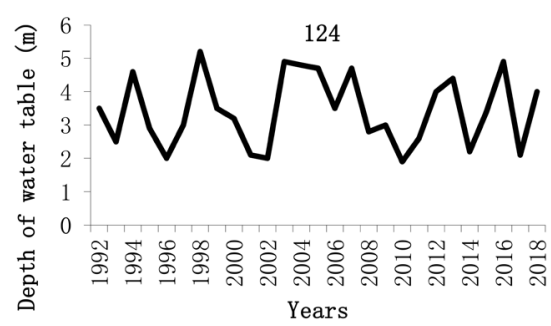



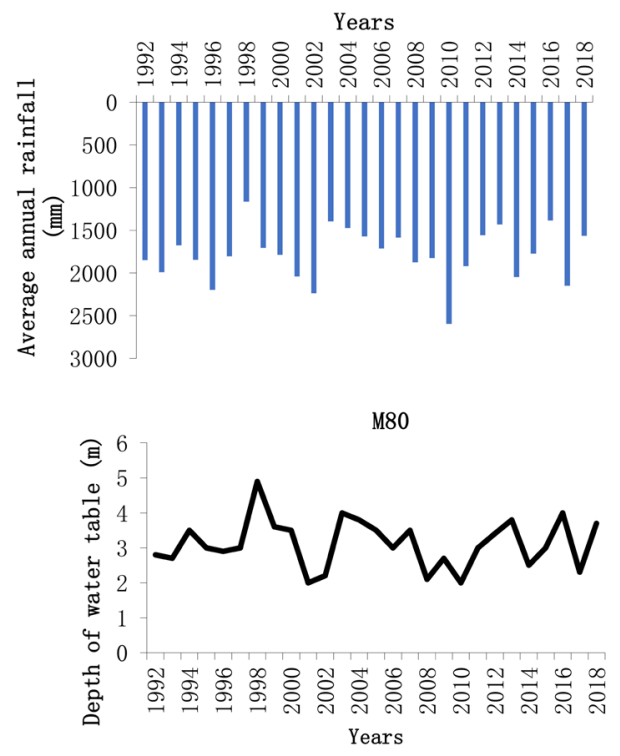

Years

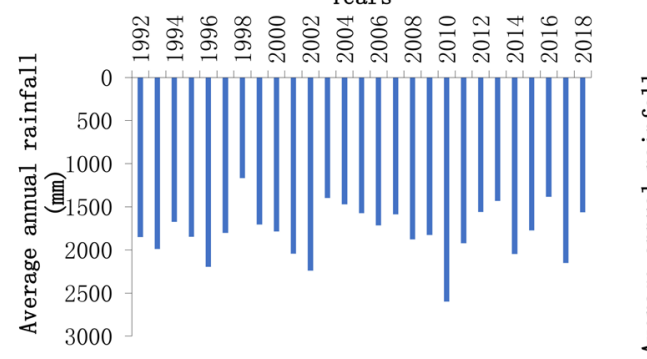

M92

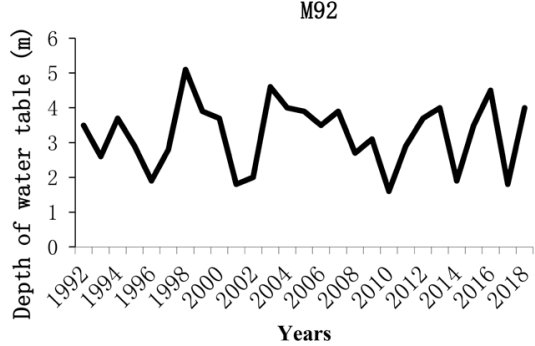

Years

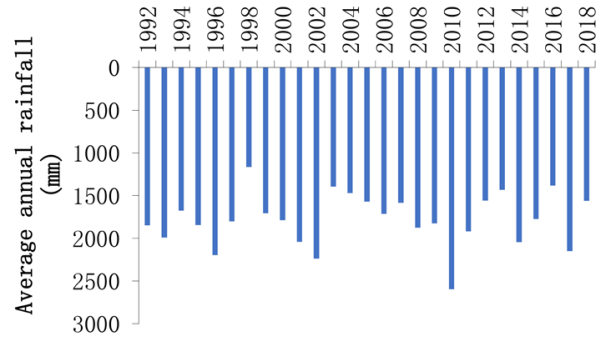

M52

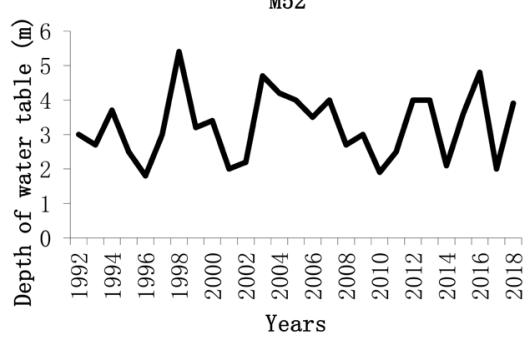

Years

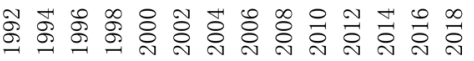

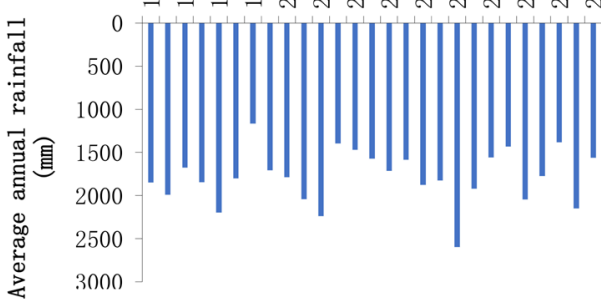

040

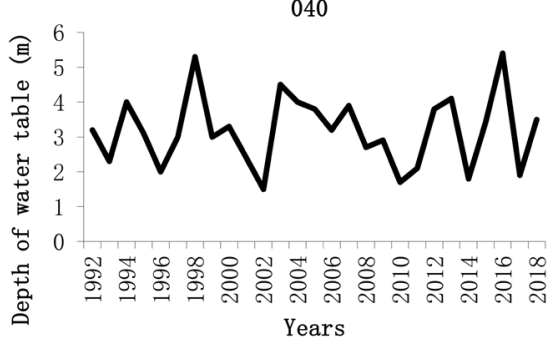

Figure 3. Average annual rainfall and piezometric fluctuations of the piezometers in the area during the period 1992-2018.

\subsubsection{Assessment of Groundwater Recharge}

\section{1) Application of the water balance method over the period 1969-2018}

The average annual rainfall over the period $1969-2018$ is estimated at 1771 $\mathrm{mm}$. Of this amount, $1300 \mathrm{~mm}$ reach the atmosphere by evapotranspiration and $471 \mathrm{~mm}$ of effective rainfall on average feeds the surface water and groundwater resources. Thus, the estimated infiltration is $205 \mathrm{~mm}$ or $11.57 \%$ of the rainfall. Of the total rainfall in the region, only $11.57 \%$ infiltrates to participate in the groundwater recharge process, Table 15 therefore presents the parameters of the water balance.

\section{2) Ten-year water balance}

Effective rainfall varies greatly from one decade to another. The rather rainy period 1969-1978 was followed by years with cumulative rainfall deficits and below 


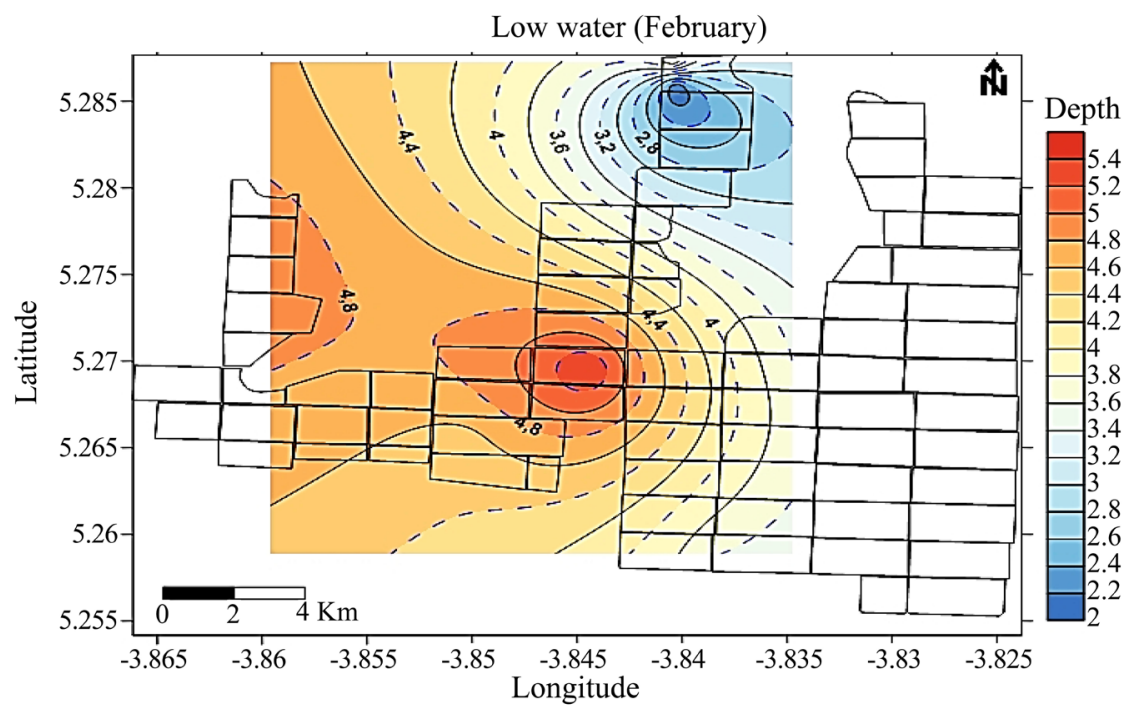

Figure 4. Piezometric map of the water table of the Marc Delorme station in low water (February).

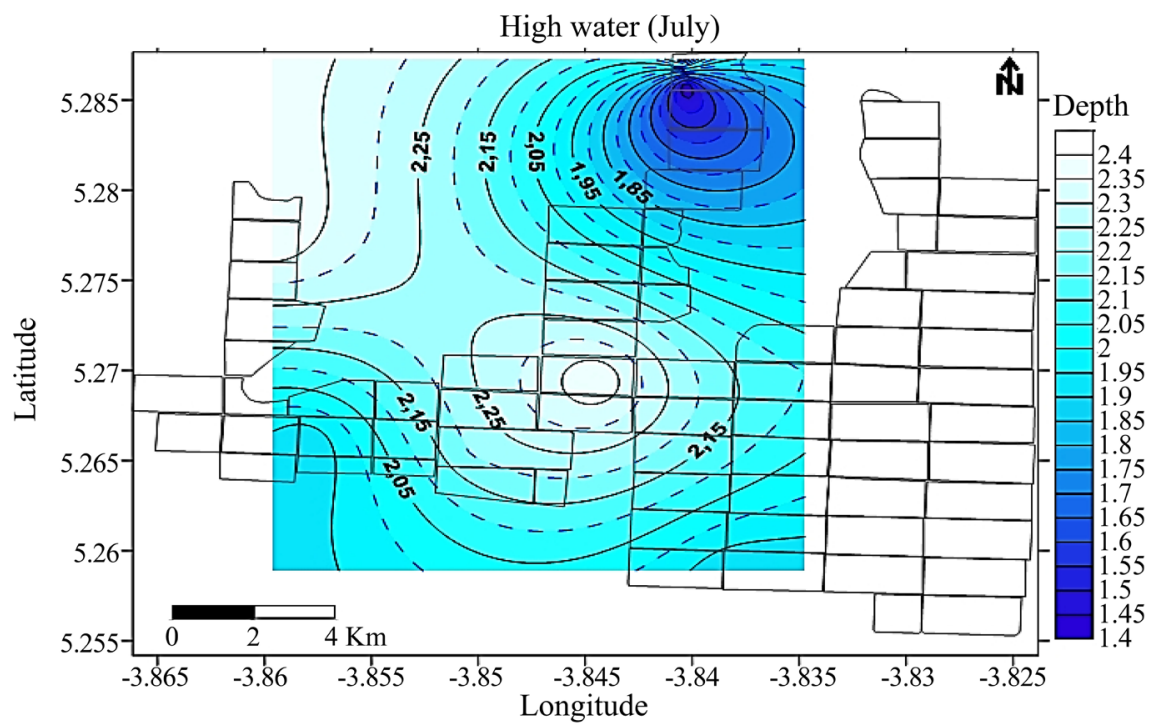

Figure 5. Piezometric map of the water table of the Marc Delorme station in high water (July).

Table 15. Parameters of the hydrological balance of the Marc Delorme station.

\begin{tabular}{cc}
\hline Parameters & Quantity (mm) \\
\hline Average rainfall & 1771 \\
PET & 1584 \\
ETa & 1300 \\
Surplus (R + I) & 471 \\
Runoff & 266 \\
Infiltration & 205 \\
Balance sheet deficit & 285 \\
\hline
\end{tabular}


average effective rainfall $(486.2 \mathrm{~mm})$. Average effective rainfall fell from $661 \mathrm{~mm}$ during the 1969-1978 decade to $395 \mathrm{~mm}$ during the 2009-2018 decade, a drop of $40.24 \%$ (Table 16). The decrease in the decadal average rainfall leads to a decrease in the decadal effective rainfall. However, despite the increase in rainfall in the last decade 2009-2018 (1825 mm) compared to the previous one 1999-2008 (1739 $\mathrm{mm})$, the effective rainfall has decreased. It decreased from 436 $\mathrm{mm}$ (1999-2008) to $395 \mathrm{~mm}$ (2009-2018). Between these two decades, the temperature increased from $26.3^{\circ} \mathrm{C}$ to $26.9^{\circ} \mathrm{C}$. The ETa is function of temperature and it went from $1430 \mathrm{~mm}$ to $1303 \mathrm{~mm}$ in the decade 2009-2018 to the decade 1999-2008. These observations show that effective rainfall is dependent on certain parameters, namely rainfall and temperature.

\section{3) Water balance of the area before and after the 1982 break}

The average annual rainfall, which was $1962 \mathrm{~mm}$ before the rainfall disruption (1969-1982), decreased to $1710 \mathrm{~mm}$ after the rainfall disruption (1983-2018), i.e. a decrease of $12.84 \%$ (Table 17). The effective rainfall, estimated at $696 \mathrm{~mm}$ before the rupture, fell to $410 \mathrm{~mm}$ after the rupture, i.e., a decrease of $41.09 \%$. The water runoff decreased from $294 \mathrm{~mm}$ before the rupture to $257 \mathrm{~mm}$ after the rupture, a decrease of $12.58 \%$. The infiltrated water level decreased from 402 $\mathrm{mm}$ before the rupture to $153 \mathrm{~mm}$ after the rupture, a decrease of $61.94 \%$.

Table 16. Results of the 10-year water balance calculation in the study area from 1969 to 2018.

\begin{tabular}{ccccccc}
\hline Decades & $\begin{array}{c}\text { Average } \\
\text { rainfall } \\
(\mathrm{mm})\end{array}$ & $\begin{array}{c}\text { Temperature } \\
\left({ }^{\circ} \mathrm{C}\right)\end{array}$ & $\begin{array}{c}\text { PET } \\
\text { Average } \\
(\mathrm{mm})\end{array}$ & $\begin{array}{c}\text { ETa } \\
\text { Average } \\
(\mathrm{mm})\end{array}$ & $\begin{array}{c}\text { Effective } \\
\text { rainfall } \\
(\mathrm{mm})\end{array}$ & $\begin{array}{c}\text { Balance } \\
\text { sheet deficit } \\
(\mathrm{mm})\end{array}$ \\
\hline $1969-1978$ & 1941 & 26.1 & 1575 & 1280 & 661 & 295 \\
$1979-1988$ & 1706 & 26.1 & 1548 & 1216 & 490 & 332 \\
$1989-1998$ & 1692 & 26.2 & 1598 & 1243 & 449 & 355 \\
$1999-2008$ & 1739 & 26.3 & 1583 & 1303 & 436 & 280 \\
$2009-2018$ & 1825 & 26.9 & 1618 & 1430 & 395 & 188 \\
\hline
\end{tabular}

Table 17. Water balance before and after the 1982 rupture in the study area from 1969 to 2018.

\begin{tabular}{ccc}
\hline Parameters & Before break (1969-1982) & After break (1983-2018) \\
\hline Rainfall (mm) & 1962 & 1710 \\
PET (mm) & 1563 & 1592 \\
ETa (mm) & 1266 & 1300 \\
Effective rainfall (P-ETa) & 696 & 410 \\
runoff (R) (mm) & 294 & 257 \\
Infiltration (mm) & 402 & 153 \\
\hline
\end{tabular}




\section{Discussions}

Statistical methods (trend tests, break tests, standardized precipitation index, etc.) agree on the reality of a significant decrease in rainfall in the study area. The results of the indices for gradual changes in the rainfall series over the period 1961 to 2018 indicate a general downward trend. A significant upward trend is also observed in air temperature, insolation and evaporation. This climatic variability is marked by a rainfall break in 1982. This result is in line with work in West and Central Africa in general [29] [30] and in Côte d'Ivoire specially [18] [31], which indicate a general decrease in rainfall. The break shows a downward trend in annual rainfall from the 1970s onwards and is consistent with the very marked drought period in Ivory Coast from 1982 to 1983 [32]. The rainfall deficit calculated in relation to the date of the break in the annual totals is less than 20\%. According to [33], rainfall deficits are sometimes less than $20 \%$ in some localities in West Africa. This is the case at the Marc Delorme research station with $15 \%$. The two main seasons, dry and rainy, are the most affected by the drop in rainfall, with average deficits of $15 \%$ and $25 \%$ respectively. The observed decrease in rainfall in the wet and dry months shows that the wet months as a whole are experiencing a downward trend. This highlights the decisive role of the wet months in the rainfall decline of the time series in the area. This finding was confirmed by [30] which pointed out apronounced rainfall deterioration in the rainy months in the Beninese basin of the Niger River. The decrease in annual rainfalls amounts is synchronous with that of the frequency of rainy days. This observation was also made by [34]. In the study area, the frequencies of rainy days have decreased significantly with a break in 1982. The number of rainy days decreased from 121 days at the time of the break in 1982, to 100 days on average after the break, i.e. a decrease of 17.35\% over the period 1961-2018. These results corroborate those of [35], which noted this decrease in the number of rainy days in West Africa. The decrease in the frequencies of rainy days concerns all rainfall classes, but rainfall amounts between 10 and $30 \mathrm{~mm}$ (P2) and $>50 \mathrm{~mm}(\mathrm{P} 4)$ are the most affected, with respective decreases of $32.50 \%$ and $40 \%$. The heterogeneous distribution of rainfall observed over the whole of south-eastern Côte d'Ivoire is justified by the latitudinal position of the Intertropical Convergence Zone (ITCZ) and the intensity of the convection [36]. It is also marked by the conversion of forest cover into alternative cover (urbanization, large-scale fields). In this context, it is therefore feared that seasonal rainfall variables will decrease in the coming decades as a result of an increase in air temperature and a decrease in relative humidity.

The irregularity of rainfall observed in the area has been accompanied by a disruption of the differents seasons. Indeed, the average start and end dates of the rainy season are variable. The onset of the rainy seasons after the break was delayed, leading to a shortening of the rainy seasons. Indeed, the start of the rains has a higher interannual variability than the end. This fluctuation in the start date of the rainy season requires an adaptation of agricultural activities, 
because knowledge of the dates of the start of the rains is very important for the planning of cultivation operations. This relationship between the onset and length of rainy seasons has been demonstrated in the work done by [37] [38]. Predicting the length of the season is an important element that could contribute to the choice of crop variety and planting period for young coconut plants so that they benefit from a useful amount of water for their growth. Therefore, the farmer will be able to anticipate the manifestation of water stress at a critical stage of coconut tree development, which conditions an optimal production of coconut, by adaptive measures. These observations are in line with those of [39] which showed that, in case of drought, one of the main risks is that the water deficit coincides with a sensitive millet phase.

Analysis of the results of Standardised Precipitation and Evapotranspiration Index (SPEI) revealed that the south-east of Côte d'Ivoire is experiencing a significant rainfall deficit after the 1980s. These results confirm the research done by [6] which showed the persistence of drought during this period in West and Central Africa. In Ivory Coast, the work of [40] has shown that the three decades 1970-1979, 1980-1989, and 1990-1999 were dry periods. This trend of increasing dry years will therefore have a significant impact on the agricultural sector, leading to job losses, higher food prices and other socio-economic impacts [41]. In addition, a decrease in rainfall combined with other extreme climatic factors (temperature increase, evapotranspiration), especially in the area, will aggravate drought conditions (water stress), leading to a significant decline in coconut production.

Analysis of the piezometric curves shows that recharge occurs mainly during the rainy season in all the piezometers. The seasonal piezometric rises highlighted are observed at the end of the rainy season and show that the shallow aquifers are recharged throughout the study area. The intensity of these piezometric rises differs according to the distance to the surface watercourse (Ebrié Lagoon) and the land use. These different factors influence the time of recharge and the rate of recharge. The accumulation of deficit years after 1982 has resulted in a decrease in recharge, leading to a steady decline in the depth of the water table. Since the soil structure is predominantly sandy, the permeability and porosity are relatively high and the water table is recharged just after a rainfall event. As a result, the water level and the intensity of well recharge are dependent on seasonal fluctuations. According to [42] [43], the accumulation of rainfall deficits leads to a significant decrease in groundwater recharge. However, some groundwater tables in the tertiary sedimentary basins of Niger have recorded an increase in recharge, despite the reduction in rainfall [44]. This increase could be due to low evapotranspiration, and especially to an increase in runoff caused by deforestation, with a higher recharge, thanks to the surface water accumulated in the endoreic shallows. The comparison of surpluses obtained from the water balance gives an idea of the impact of rainfall changes on aquifer recharge. Thus, the infiltrated water level, which constitutes the part of the pre- 
cipitation likely to reach the groundwater, fell from $402 \mathrm{~mm}$ before the rupture to $153 \mathrm{~mm}$ after the rupture, i.e. a drop of $61.94 \%$. This situation is in line with that mentioned in the work of [45] [46] on the impact of climate variability on water resources in Côte d'Ivoire.

\section{Conclusion}

This study has enabled us to characterise the main manifestations of climatic variability in the South-East of Côte d'Ivoire (Marc Delorme Station) and its impact on groundwater recharge. Indeed, trend detection tests such as the Mann-Kendall test and linear regression applied to the rainfall series show a significant downward trend. As for the average temperature, minimum temperature, maximum temperature, insolation evaporation series, they show a significant upward trend. The statistical tests for detecting breaks (Pettitt test, Hubert segmentation procedure, Lee and Heghinian Bayesian procedure) show a break in 1982, which highlights a succession of wet and dry periods. This break marks a change in the rainfall regime, resulting in a 15\% decrease in rainfall all over the study area. In the area, after the break in 1982, the main rainy season occurs on average in the third dekad of April and ends in August. It lasts on average 104 days. As for the short rainy season, it begins on average in October and ends in the second dekad of December. This season lasts on average 54 days. These predictions were made possible by linear regressions with correlation coefficients ranging from 0.88 to 0.97 . In view of the climatic irregularities observed in the study area over the period considered, knowledge of the rainfall regime is of paramount importance for determining the agricultural calendar. The evolution of the SPEI time series is different from one-time scale to another. However, the most remarkable droughts by their frequency are of moderate types. Water resources have suffered a significant decrease in supply as a result of this climate change. However, after the break in 1982, the water balance shows a $13 \%$ decrease in surface runoff and a $62 \%$ decrease in effective infiltration on average per year, mainly due to the accumulation of rainfall deficits. This rainfall regression is also marked by a drop in monthly rainfall amounts, with a $17.35 \%$ drop in the number of rainy days.

\section{Acknowledgements}

The authors of this article thank CNRA (National Center for Agronomic Research) for his collaboration in the realization of this research project. They also thank the Laboratory of Soil, Water and Geo-materials Sciences (LSWGS) of the University Félix Houphouët Boigny and the Laboratory, Geosciences and Environment, Nangui Abrogoua University (UNA) for the reception.

\section{Conflicts of Interest}

The authors declare no conflicts of interest regarding the publication of this paper. 


\section{References}

[1] IPCC (2018) IPCC Special Report on the Implications of Global Warming by $1.5^{\circ} \mathrm{C}$ above Pre-Industrial Levels and Associated Global Greenhouse Gas Emission Trajectories for Strengthening the Global Response to Climate Change, Sustainable Development and Poverty Alleviation. 32 p. https://www.ipcc.ch/

[2] Ba, D.D. (2018) Sécheresse climatique, dynamique actuelle et perspectives des activités agropastorales dans le Ferlo et la Moyenne Vallée du fleuve Sénégal (Région de Matam). Single PhD Thesis, Gaston Berger University of Saint-Louis, Geography Section, $196 \mathrm{p}$.

[3] Ballouche, A. (2013) Contribution à l'histoire récente de la végétation du Bas-Loukkos (province of Larache, Morocco). Physio-Géo, 7, 67-82.

https://doi.org/10.4000/physio-geo.3426

[4] GIEC (2007) Summary for Policy Makers, In: Parry, M.L., Canziani, O.F., Pa-lutikof J.P., van der Linden, P.J. and Hanson, C.E., Eds., Taking Stock of Climate Change: Impacts, Adaptation and Vulnerability, Report of the Intergovernmental Panel on Climate Change, Cambridge University Press, Cambridge, 114.

[5] Servat, E., Paturel, J.-E., Lubes-Niel, H., Kouamé, B., Masson, J.-M., Travaglio, M. and Marieu, B. (1999) Different Aspects of Rainfall Variability in Non-Sahelian West and Central Africa. Revue des Sciences de P Eau, 12, 363-387. https://doi.org/10.7202/705356ar

[6] Lebel, T., Diedhiou, A. and Laurent, H. (2003) Seasonal Cycle and Interannual Variability of the Sahelian Rainfall at Hydrological Scales. Journal of Geophysical Research, 108, 1-11. https://doi.org/10.1029/2001JD001580

[7] Gachon, P., Bokoye, A.I. and Cotnoir, A. (2007) Working Group II: Variability, Extremes and Climate Change in the Sahel: From Observation to Modeling. Report on Canadian Contributions to the CIDA-CILSS Project (A030978-002) Climate Change Adaptation Capacity Support, Montreal, 208 p.

[8] Karimou Barke, M., Ambouta, K., Sarr, B. and Tychon, B. (2015) Analysis of Extreme Climate Events in Southeast Niger. 28th Colloquium of the International Climatological Association, University of Liege, Belgium, 537-542.

[9] N'goran, A. and Zakra, N. (2003) Improvement of the Income of Coconut Growers on the Ivorian Coast through the Use of the Coconut/Acacia Association. CNRA Research Project Marc Delorme-Banque Africaine de Développement, 10 p.

[10] Minagri (2007) Yearbook of Agricultural Statistics. 42 p.

[11] Noufé, D. (2012) Climate Change and Agriculture: The Case of Eastern Côte d'Ivoire. Saarbrücken (Paf). 516 p.

[12] Assa, R.R.A., Konan, J.L., Nemlin, J., Prades, A., Agbo, N. and Sie, R.S. (2006) Diagnosis of Peasant Coconut Groves along the Ivorian Coast. The Science of Nature, 3, 113-120.

[13] Konan, J.L., Bourdeix, R., Sangare, A. and Mondeil, F. (2006) Caractérisation de quelques cultivars de cocotier (Cocos nucifera L.) tolérant à la sécheresse en Côte d'Ivoire. Agronomie Africaine, 18, 145-156. https://doi.org/10.4314/aga.v18i2.1688

[14] Konan, J.L. (2005) Status of coconut genetic resources research in Côte d'Ivoire. In: Ramanatha, R.V. and Olivier, J., Eds., Coconut Genetic Resources, IPGRI, Selangor Darul Ehsan, 654-660.

[15] Roose, E. and Cheroux, M. (1966) Soils of the Sedimentary Basin of Côte d'Ivoire. O.R.S.T.O.M. Adiopodoumé, multig., 51-92.

[16] Tie Bi, Y. (1984) Contribution to the Study of Sandy Soils of the Lower Ivory Coast, 
Cultivated with Coconut Palms, and Definition of Thresholds for the Use of Phosphate Manure. PhD Thesis. University of Cocody, Abidjan, 182.

[17] Ake, G.E. (2010) Impacts of Climate Variability and Anthropogenic Pressures on Water Resources in the Bonoua Region (South-East Côte d'Ivoire). Thesis by Doctorate, University of Cocody, Abidjan, $204 \mathrm{p}$.

[18] Traoré, A. (2016) Impacts of Climate Change and Changes in Land Cover and Land Use on Water Resources in the Lagoon Environment of Aghien and Potou Lagoon (Southeast Côte d'Ivoire). Thesis of the University Félix Houphouët Boigny of COCODY, Abidjan, 248 p.

[19] Tastet, J.P. and Guiral, D. (1994) Géologie et sédimentologie: Dans Environnement et ressources aquatiques de Côte-d'Ivoire. In: Durand, J.-R., Duffour, P., Guiral, D. and Zabi, S.G.F., Eds., Tome II-Les milieux lagunaires, Editions de l'ORSTOM, Paris, 35-57.

[20] Aghui, N. and Biemi, J. (1984) Géologie et Hydrogéologie des nappes de la région d'Abidjan et risques de contaminations. Annales de l Université de Côte d Ivoire, série C(Sciences), 20, 313-347.

[21] Boyer, J.F. (1998) Khronostat-Statistical Time Series Analyses Software. Mont-Pellier: UMR 5569 Hydrosciences, IRD—Maison des Sciences de l'Eau.

[22] Keyantash, J.A. and Dracup, J.A. (2002) The Quantification of Drought: An Evaluation of Drought Indices. Bulletin of the American Meteorological Society, 83, 1167-1180. https://doi.org/10.1175/1520-0477-83.8.1167

[23] Vicente-Serrano, S.M., Beguería, S. and López-Moreno, J.I. (2010) A Multiscalar Drought Index Sensitive to Global Warming: The Standardized Precipitation Evapotranspiration Index SPEI. Journal of Climate, 23, 1696-1718.

https://doi.org/10.1175/2009JCLI2909.1

[24] Beguería, S., Vicente-Serrano, S.M., Reig, F. and Latorre, B. (2014) Standardized Precipitation Evapotranspiration Index (SPEI) Revisited: Parameter Fitting, Evapotranspiration Models, Tools, Datasets and Drought Monitoring. International Journal of Climatology, 34, 3001-3023. https://doi.org/10.1002/joc.3887

[25] Sivakumar, M.V.K. (1988) Predicting Rainy Season Potential from the Onset of Rains in Southern Sahelian and Sudanian Climatic Zones of West Africa. Agricultural and Forest Meteorology, 42, 295-305.

https://doi.org/10.1016/0168-1923(88)90039-1

[26] Sarr, B. (2007) User Manual for Agrometeorological Engineers. Center Régional AGHYMET, Niamey, 72 p.

[27] Goula, B.T., Srohourou, B., Brida, A., N’zué, K.A. and Goroza, G. (2010) Determination and Variability of Growing Seasons in Côte d'Ivoire. International Journal of Engineering Science, 2, 5993-6003.

[28] Dekoula, C.S., Kouame, B., N’goran, E.K., Yao, F.G., Ehounou, J.N. and Soro, N. (2018) Impact of Rainfall Variability on the Cropping Season in the Cotton Production Zone in Côte d'Ivoire. European Scientific Journal, ESJ, 14, 143-156. https://doi.org/10.19044/esj.2018.v14n12p143

[29] Ardoin-Bardin, S. (2004) Hydroclimatic Variability and Impacts on Water Resources of Large Watersheds in the Sudano-Sahelian Zone. PhD Thesis, University of Montpellier II, Montpellier, $437 \mathrm{p}$.

[30] Vissin, E., Houndenou, C. and Perard, J. (2007) Rainfall Drought and Drying Up in the Mekrou Basin (Benin, West Africa). Proceedings of the 10 th Colloquium of AIC, Carthage, Tunis, 568-573.

[31] Amani, M.K., Adjoa, V.S.A., Koffi, E.K., Kouakou, B.D., Koffi, F.K. and Biemi, J. (2017) 
Analyse de la persistance de la sécheresse en Afrique de l'Ouest: Caractérisation de la variabilité climatique récente en Côte d'Ivoire. Environmental and Water Sciences, Public Heath and Territorial Intelligence, 1, 47-59.

[32] Brou, Y.T. (2005) Climate, socio-economic changes and landscapes in Côte d'Ivoire. Mémoire de l'Habilitation à Diriger des Recherches, Université des Sciences et Technologies de Lille, Lille, 212 p.

[33] Kouassi, A.M., Kouame, K.F., Koffi, Y.B., Dje, K.B., Paturel, J.E. and Oulare, S. (2010) Analysis of Climate Variability and Its Influences on Seasonal Rainfall Patterns in West Africa: Case of the N'zi (Bandama) Watershed in Côte d'Ivoire. $C y$ bergeo: European Journal of Geography, Article 513.

http://cybergeo.revues.org/23388

https://doi.org/10.4000/cybergeo.23388

[34] Paturel, J., Servat, E. and Delattre, M. (1998) Analyse des séries pluviométriques de longue durée en Afrique de l'Ouest et Centrale non sahélienne dans un contexte de variabilité climatique. Hydrological Sciences Journal, 43, 937-945. https://doi.org/10.1080/02626669809492188

[35] Bigot, S., Brou, T.Y., Oszwald, J. and Diedhiou, A. (2005) Factors of Rainfall Variability in Côte d'Ivoire and Relations with Certain Environmental Modifications. Sécheresse, 16, 5-13.

[36] Houndenou, C. and Hernandez, K. (2010) Modification of the Rainy Season in Atakora (1961-1990). An Example of Drought in North-Eastern Benin (West Africa). Drought, 9, 23-34.

[37] Kouassi, A.M., Kouassi, J., Dje, K.B., Kouamé, K.F. and Biemi, J. (2018) Analysis of the Length of the Rainy Season as a Function of the Start Date of the Rains in West Africa: The Case of the Bandama Catchment Area in Côte d'Ivoire, Agronomie Africaine, 30, 1-10.

[38] Vaksmann, M. and Traoré, M. (1991) Evaluation and Monitoring of Agricultural Production in Relation to Climate and the Environment. Project ESPACE IER-CIRAD/ Bamako, Mali, 23 p.

[39] Lebel, T. and Ali, A. (2009) Recent Trends in the Central and Western Sahel Rainfall Regime (1990-2007). Journal of Hydrology, 375, 52-64. https://doi.org/10.1016/j.jhydrol.2008.11.030

[40] Goula, B.T.A., Savané, I., Konan, B., Fadika, V. and Kouadio, G.B. (2006) Impact of Climate Variability on Water Resources in the N'Zo and N'Zi Watersheds in Côte d'Ivoire (Humid Tropical Africa). Vertigo, 7, 1-12.

[41] Botai, C.M., Botai, J.O., de Wit, J.P., Ncongwane, K.P. and Adeola, A.M. (2005) (2017) Drought Characteristics over the Western Cape Province, South Africa. Water, 9, 876. https://doi.org/10.3390/w9110876

[42] Orange, D., Wesselink, A., Mahe, G. and Feizoure, C. (1997) The Effects of Climate Changes on River Baseflow and Aquifer Storage in Central Africa. IAHS Publication, No. 240, 113-123.

[43] Sangaré, S., Mahe, G., Paturel, J.E. and Bangoura, Y. (2002) Water Balance of the Niger River in Guinea from 1950 to 2000. Sud Sciences et Technologies, EIER, Ouagadougou, No. 9, 21-33.

[44] Favreau, G. (2002) Deforestation: Origin of Increased Recharge and Nitrate in Semi-Arid Open Aquifers (Sahel, Niger). Pangea, 38, 25-34.

[45] Kanohin, F., Saley, M.B. and Savané, I. (2015) Impacts of Climate Variability on Water Resources and Human Activities in the Humid Tropics: The Case of the Daoukro Region in Côte d'Ivoire. European Journal of Scientific Research, 26, 209-222. 
[46] Kouakou, K.E. (2011) Impacts of Climate Variability and Change on Water Re-sources in West Africa: The Case of the Comoé Catchment Area. PhD Thesis from the University of Cocody, Abidjan, 204 p. 